\title{
CORPORATE GOVERNANCE, FINANCIAL LEVERAGE, AND PERFORMANCE OF SHARIA MANUFACTURING COMPANIES ON THE INDONESIA STOCK EXCHANGE
}

\author{
Muhamad Umar Mai ${ }^{*}$, Mochamad Edman Syarief ${ }^{2}$, Kristianingsih $^{3}$ \\ ${ }^{123}$ Jurusan Akuntansi Politeknik Negeri Bandung \\ Jl. Gegerkalong Hilir, Ds. Ciwaruga, Bandung, Indonesia \\ ${ }^{*}$ umar.mai@polban.ac.id, ${ }^{2}$ edsykemp@gmail.com, ${ }^{3}$ mep2008_kries@yahoo.com
}

\begin{abstract}
This paper discusses the impact of corporate governance on the leverage effect and the leverage effect on corporate performance. The study was conducted on Islamic manufacturing companies on the Indonesia Stock Exchange during the period 2012 to 2018. The data analytics method used Partial Least Square (PLS) which was handled with the WarpPLS application. The results show that almost all proxies of the corporate governance variable negatively affect financial leverage variable, except for the Independent Board of Commissioners (ICB) which has a positive effect on book leverage (BLEV). Furthermore, financial leverage as proxy by book leverage (BLEV) shows a positive effect on market performance (TBQ) and negative effect on book performance (ROA). The financial leverage effect by market leverage variable (VEML) has a negative effect on market performance (TBQ) as well as on accounting performance (ROA). An important implication of this study is that in general, Shariah manufacturing companies that are more profitable tend to reduce their financial leverage, and investors can better recognize the relationship between financial leverage decisions and firm performance.
\end{abstract}

Keywords: Corporate governance; Financial leverage; Firm permance

*Correspondent author

\section{Introduction}

Since the proposition of irrelevance theory was put forward by Modigliani \& Miller (1958), capital structure decisions have been a topic of continuous research for more than six decades (Chakrabarti \& Chakrabarti, 2019). The capital structure study addresses two specific questions: which factors determine the capital structure and whether capital structure decisions affect the corporation's performance. Several studies on the determinants of capital structure with different axes have been carried out previously, such as Martin \& Saona (2017) on factors specific to the enterprise. The study of Zaid et al. (2020) and Feng, Hassan, \& Elamer (2020) focus on corporate governance. In addition, Chow et al., (2018) underline that macro-economic factors such as exchange rates, inflation rates and interest rates are important determinants of capital structure. Despite the many studies that have

Received: 2020-12-17 | Reviced: 2021-05-30 | Accepted: 2021-07-20

Indexed : Sinta, DOAJ, Garuda, Crossref, Google Scholar | DOI: 10.29313/amwaluna.v5i2.7053 
been conducted, to date there is no agreement on the most important determinants of the enterprise's capital structure (Yildirim et al., 2018).

The association between capital structure and company performance has also been widely studied, but the results of this study also show mixed results. Several studies suggest that the structure of capital has a positive impact on business performance (Piaw and Jais, 2014; Detthamrong, Chancharat and Vithessonthi, 2017). Several other studies have demonstrated that capital structure decisions are negatively linked to company performance (For example, Le \& Phan, 2017; Vo \& Ellis, 2017). Meanwhile, the results of the study by Li, Niskanen, \& Niskanen (2019) determined that there is no substantial affiliation between capital structure and the performance of SMEs with high credit risk.

Decision of the Capital Market and Financial Institution Supervisory Agency Number Kep-208/B1/2012 concerning Standards and Issuance of Sharia Securities Lists affirms that companies that can be included in the Indonesian Sharia Stock Index (ISSI) category have to meet two financial ratios. First, the sum of interestbased debt compared to total assets of a maximum of $45 \%$; Second, the total of nonhalal income is compared with the total operating income and other income of a maximum of $10 \%$.

Referring to the first limitation, the results of observations on the average Book Leverage (BLEV) of 61 ISSI manufacturing companies and 42 Non-ISSI manufacturing companies listed on the Indonesia Stock Exchange (IDX) for the 2012-2018 period are shown in Figure 1.

Figure 1. Average BLEV of ISSI and NonISSI manufacturing companies

\section{Book Leverage (BLEV) ISSI dan Non-ISSI}

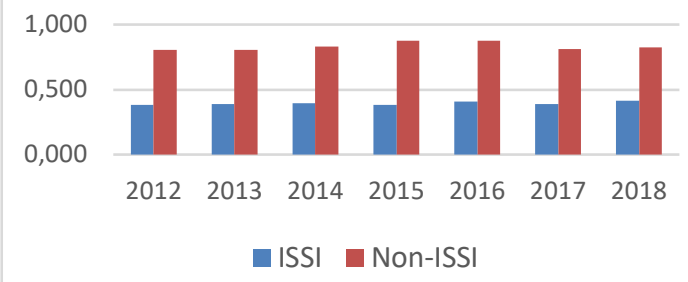

Source: Financial statements of ISSI and Non-ISSI manufacturing companies on the IDX for the 2012-2018 period.

Referring to the second limitation, the results of observations on book performance, namely the Return on Assets (ROA) of 61 ISSI manufacturing companies and 42 non-ISSI companies listed on the Indonesia Stock Exchange (IDX) during the 2012-2018 period are shown in Figure 2.

Figure 2. Average ROA of ISSI and NonISSI manufacturing companies 


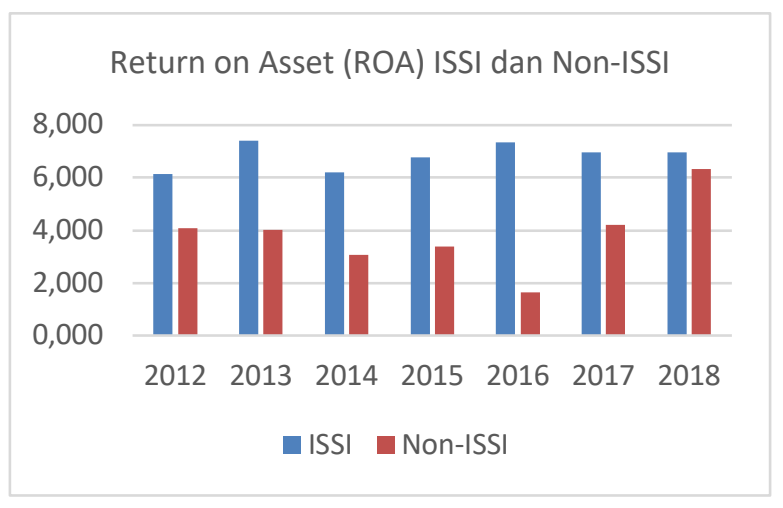

Source: Financial statements of ISSI and Non-ISSI manufacturing companies on the IDX for the 2012-2018 period.

Figure 1 shows the average BLEV of ISSI manufacturing companies is much smaller than that of Non-ISSI. Figure 2 shows the average ROA of ISSI manufacturing companies is greater than that of Non-ISSI. The phenomena shown in Figures 1 and 2 indicate a relationship between decisions on capital structure and the performance of manufacturing enterprises. Imamah et al., (2019) explained that over the last two decades, the development of the Islamic economy has portrayed a notable role in encouraging the Islamic corporate governance system, such as the publication of Islamic principles on Corporate Governance. Business managers in Islamic countries must not only maximise the company's performance, but also follow the principles of Islamic Sharia law. Therefore, corporate governance owned by ISSI class companies is expected to play an important role in determining capital structure decisions. In particular by encouraging companies to comply with the Decree of the Capital Markets and Financial Institutions Supervisory Agency Number Kep208/B1/2012. Furthermore, the capital structure decision of ISSI category companies is predicted to be related to performance achievement.

The objective of this study is to examine the effect of corporate governance on the capital structure (leverage) and the effect of financial leverage on corporate performance. The research was conducted on a manufacturing company in the ISSI (Sharia) category which was listed on the Indonesia Stock Exchange. The basis for selecting a manufacture company as the object of research is to avoid industry bias and a manufacturing company is one of the largest industries on the Indonesia Stock Exchange.

\section{Discussion}

\section{A. Literature Review}

Agent theory examines problems that occur in businesses due to the separation between owners (principles) and managers (agents) and explains ways to overcome these problems (Panda \& Leepsa, 2017). Corporate governance is a system that not only improves the association between shareholders, managers, and investors, but also approves that suitable reserves are provided among participating users (Al- 
ahdal et al., 2020). Financial leverage is influenced by the firm 's sole features and conflicts of interest concerning managers and shareholders (Chang et al., 2014). Corporate governance is an important instrument to reduce agent and shareholder conflicts that can influence the decisions of capital structure (Detthamrong et al., 2017).

\section{Size of the board and financial leverage.}

The board of directors plays an important role in reducing corporate failures, and is responsible for monitoring key activities and approving strategic decisions (Chancharat et al., 2012). Previous studies have shown mixed results in terms of the relationship between board size and fiscal leverage. Sewpersadh (2019) demonstrates that the size of the board negatively impacts the leverage effect. In contrast, Usman et al., (2019) and Feng et al. (2020) found that corporations with larger boards of directors have more financial leverage. The positive relationship between board size and financial leverage supports the view that with a larger board size, companies can use it to gain greater access to external financing. However, Hussainey and Aljifri (2012) suggested that board size is not related to leverage.

\section{Women's Board of Directors and}

\section{Financial Leverage}

Women directors have more skills, legal knowledge, human resource management, communications and public relations than male directors (Zelechowski \& Bilimoria, 2004). Recently, stakeholders have increased their emphasis on gender diversity on corporate boards. This is because gender diversity can affect the efficacy of the company's board of directors (Gyapong et al., 2019). Firms with a more gender-diverse board of directors borrow at lower costs (Usman et al. (2019). Elmagrhiet al., (2018) demonstrated that boards with more gender diversity tend to use less debt. Schicks ( 2014) report that male borrowers have a higher debt risk than women.Strøm et al., (2014) and Faccio et al., (2016) show that entities headed by female CEOs are less leveraged than similar entities headed by male CEOs. .

\section{Independent Board of Commissioners and Financial Leverage}

In Indonesia, there is an independent board of commissioners. Financial Services Authority Regulation Number 33/POJK.04/2014 concerning the Board of Directors and Board of Commissioners of Public Companies, states that the number of Independent Commissioners must be at least $30 \%$ of the total members of the Board of Commissioners. Usman et al. (2019) indicates that companies whose independent boards are larger pay less for debt financing. Dimitropoulos (2014) stated that the independence of the board has an adverse 
affiliation with external financing. However, Jiraporn et al. (2012) asserted that independent boards have knowledge and information that allows companies to have higher leverage. Zaid et al. (2020) and Chow et al. (2018) found an affirmative relationship between board independent and financial leverage.

\section{Audit Committee Size and Financial}

\section{Leverage}

The audit committee is qualified for rendering aid in deciding external auditors for the board of directors, commanding management, building trust for the accuracy, reliability, and quality of financial reports (Anderson et al., 2004). Studies of the link between the size of the audit committee and the leverage effect show mixed results. First of all Chen et al. , (2016) conclude that the audited financial statements provide significant supplemental information on the company's credit risk to capital providers. This naturally leads to strict credit approvals. On the other hand, Detthamrong et al. [2018] explained that the effectiveness of the audit committee enables companies to have better access to external financing, which is related to the leverage effect. However, the relationship may be positive or negative, based on the initial debt level. A positive relationship, the audit committee enables the company to increase the leverage effect as a result of the improved information perceived by the market. A negative relationship may occur if the company's current debt load is deemed too high.

\section{Financial Leverage and firm performance}

Modigliani and Miller (1958) argued that the capital structure is irrelevant in determining the value of the business, which is supported by Connelly et al. (2012). However, the growing financial literature reports combined empirical evidence on the connection within financial leverage and firm performance. On the one hand, several studies show a positive relationship between financial leverage and corporate performance, which is in line with the tradeoff theory (eg, Degryse et al., 2012; Piaw \& Jais, 2014). On the other hand, several studies indicate a negative relationship between financial leverage and corporate performance, which is consistent with hierarchical order theory. (eg, Vo \& Ellis, 2017; Li et al., 2019; Danso et al., 2020).

\section{B. Research Methods}

The population of this study is all Islamic manufacturing companies (ISSI) listed on the Indonesia Stock Exchange for the period 2012 to 2018 . The sample is determined using purposive sampling with the criteria that companies consistently fall into the ISSI category during the observed period. The sample that meets the criteria is 
61 companies per year, so a total of 427 company-year observations. Data analysis uses Partial Least Square (PLS) which is processed with the WarpPLS application. Meanwhile, the reasons for using the WarpPLS application are: First, the data is

Tabel 1. Code, Nama dan Operasionalisasi Variabel

\begin{tabular}{|c|c|c|c|}
\hline \multicolumn{3}{|c|}{ Corporate governance } & \\
\hline Code & Variable Name & Variable Description & Referensi \\
\hline BDS & $\begin{array}{l}\text { Board of } \\
\text { Directors Size }\end{array}$ & $\begin{array}{l}\text { The sum of representatives of the } \\
\text { board of directors owned by the } \\
\text { firm. }\end{array}$ & $\begin{array}{l}\text { Chancharat et al. } \\
\text { (2012), Sewpersadh } \\
\text { (2019) }\end{array}$ \\
\hline WBD & $\begin{array}{l}\text { Women's Board } \\
\text { of Directors }\end{array}$ & $\begin{array}{l}\text { The percentage of the number of } \\
\text { female directors to the total number } \\
\text { of members of the board of } \\
\text { directors. }\end{array}$ & $\begin{array}{l}\text { Faccio, Marchica, \& } \\
\text { Mura (2016), Usman et } \\
\text { al. (2019) }\end{array}$ \\
\hline IBC & $\begin{array}{l}\text { Independent } \\
\text { Board of } \\
\text { Commissioners }\end{array}$ & $\begin{array}{l}\text { The ratio of of independent } \\
\text { commissioners to the total number } \\
\text { of members of the board of } \\
\text { commissioners. }\end{array}$ & $\begin{array}{l}\text { Chow et al. (2018), } \\
\text { Zaid et al. (2020) }\end{array}$ \\
\hline $\mathrm{ACS}$ & $\begin{array}{l}\text { Audit } \\
\text { Committee Size }\end{array}$ & $\begin{array}{l}\text { Total number of audit committee } \\
\text { members owned by the company. }\end{array}$ & $\begin{array}{l}\text { Chen, He, Ma, \& Stice } \\
\text { (2016), Detthamrong et } \\
\text { al. (2017). }\end{array}$ \\
\hline \multicolumn{4}{|c|}{ Financial leverage } \\
\hline BLEV & Book Leverage & $\begin{array}{l}\text { Total Book Value of Debt to Total } \\
\text { Asset }\end{array}$ & $\begin{array}{l}\text { Vo \& Ellis, 2017), } \\
\text { Yildirim et al. (2018). }\end{array}$ \\
\hline MLEV & $\begin{array}{l}\text { Market } \\
\text { Leverage }\end{array}$ & $\begin{array}{l}\text { Total Book Value of Debt/(Total } \\
\text { Asset - Book Value of Equity }+ \\
\text { Market Value of Equity) }\end{array}$ & $\begin{array}{l}\text { Le \& Phan (2017), } \\
\text { Yildirim et al. (2018). }\end{array}$ \\
\hline \multicolumn{4}{|c|}{ Firm performance } \\
\hline TBQ & Tobin's Q Ratio & $\begin{array}{l}\text { The market value of shares and } \\
\text { book value of debt divided by the } \\
\text { book value of total assets }\end{array}$ & $\begin{array}{l}\text { Le \& Phan (2017), } \\
\text { Imamah et al. (2019). }\end{array}$ \\
\hline ROA & Return on Assets & $\begin{array}{l}\text { The ratio of earnings after interest } \\
\text { and taxes to total assets. }\end{array}$ & $\begin{array}{l}\text { Le \& Phan (2017), } \\
\text { Imamah et al. (2019). }\end{array}$ \\
\hline
\end{tabular}

Sumber: Dari berbagai referensi yang relevan

The influence of corporate governance financial leverage on company performance on financial leverage, and the effect of are shown in the following equation model.

$$
\begin{aligned}
& \mathrm{BLEV}=\alpha_{1} \mathrm{BDS}+\alpha_{2} \mathrm{WBD}+\alpha_{3} \mathrm{IBC}+\alpha_{4} \mathrm{ACS}+\dot{\varepsilon}_{1} \\
& \mathrm{MLEV}=\beta_{1} \mathrm{BDS}+\beta_{2} \mathrm{WBD}+\beta_{3} \mathrm{IBC}+\beta_{4} \mathrm{ACS}+\dot{\varepsilon}_{2} \\
& \mathrm{TBQ}=¥_{1} \mathrm{BLEV}+¥_{2} \mathrm{MLEV}+\dot{\varepsilon}_{3}
\end{aligned}
$$




$$
\mathrm{ROA}=€_{1} \mathrm{BLEV}+€_{2} \mathrm{MLEV}+\dot{\varepsilon}_{4}
$$

\section{Results}

Descriptive statistics showing the mean, maximum, minimum, and standard

Tabe 2. Descriptif Statistic

\begin{tabular}{|l|r|r|r|r|r|r|r|r|}
\hline & \multicolumn{1}{|c|}{ TBQ } & \multicolumn{1}{c|}{ ROA } & BLEV & MLEV & BDS & WBD & IBC & ACS \\
\hline Mean & 1.928 & 6.791 & 0.396 & 0.368 & 5.162 & 0.124 & 0.392 & 3.115 \\
\hline Maximum & 37.662 & 42.530 & 1.221 & 0.945 & 15 & 0.714 & 0.800 & 5 \\
\hline Minimum & 0.102 & -29.910 & 0.009 & 0.073 & 2 & 0 & 0.300 & 1 \\
\hline Std. Dev. & 3.080 & 8.371 & 0.186 & 0.246 & 2.668 & 0.174 & 0.096 & 0.463 \\
\hline Observations & 427 & 427 & 427 & 427 & 427 & 427 & 427 & 427 \\
\hline
\end{tabular}

Source: Secondary data published by the IDX which is processed.

The mean TBQ is 1,928 with a standard foreign exchange of 3,080 , the maximum value is 37,662 and the minimum value is 0.102 . The mean ROA is $6.79 \%$ with a standard exchange rate of $8.37 \%$, the maximum value is $42.53 \%$ and the minimum value is $-29.91 \%$. The mean BLEV is $39.60 \%$ with a standard foreign exchange of $18.60 \%$, which means that $39.60 \%$ of the company's total assets are funded by debt, the maximum value is $122.10 \%$ and the minimum value is $0.9 \%$. The mean MLEV is $36.80 \%$, the standard foreign exchange is $24.6 \%$, meaning $36.80 \%$ of the company's total assets plus the difference between the book value of equity and market value of equity funded by debt, the maximum value is $94.50 \%$, and the minimum value is $7.30 \%$. The mean BDS is 5,162 , the foreign exchange standard is 2,668 , meaning the average size of the board of directors is 5 people, the maximum value is 15 people and the minimum value is 2 people. The mean WBD is $12.40 \%$, the standard deviation is $17.40 \%$, meaning the percentage of female members on the board of directors is $12.40 \%$, the maximum value is $71.40 \%$ and the minimum value is $0.00 \%$, meaning that all members of the board of directors are male. Mean ICB 0.392, standard deviation $9.60 \%$, means the percentage of independent members on the board of commissioners is $39.20 \%$, the maximum ICB value is $80 \%$ and the minimum value is $30 \%$. The mean ACS is 3.115 and the standard deviation is 0.463 , meaning that the average audit committee size is 3 people, the maximum value is 5 people and the minimum value is 1 person.

All components of the fit and quality indices model have been met very adequately, which shows that the built model has achieved the goodness of fit. It can be shown as follows: Average path coefficient $(\mathrm{APC})=0.235, \quad \mathrm{P}<0.001$; Average R-squared (ARS) $=0.303$, 
$\mathrm{P}<0.001 ; \quad$ Average adjusted $\mathrm{R}$-squared $($ AARS $)=0.297, \mathrm{P}<0.001 ;$ Average full collinearity VIF $($ AFVIF $)=1.060$, meaning that there is no multicollinearity problem between indicators and between exogenous variables; The GoF index of 0.550 is greater than 0.36 , the fit model is in the large category; Sympson's paradox ratio (SPR) index of 1,000 is greater than 0.700 ; Index R-squared contribution ratio $(\mathrm{RSCR})=1,000$ greater than 0.900; Statistical suppression ratio index $(\mathrm{SSR})=0.917$ greater than 0.700 ; Index Nonlinear bivariate causality direction ratio $(\mathrm{NLBCDR})=0.750$ which is greater than 0.700 , which means that there is no causality problem in the model built. The results of data analysis are presented in Table 3 below.

Tabel 3. Path Coefficients and P Values

\begin{tabular}{|c|c|c|c|c|c|c|c|c|}
\hline \multirow{4}{*}{$\begin{array}{l}\text { Independen } \\
\mathrm{t} \\
\text { Variable }\end{array}$} & \multicolumn{8}{|c|}{ Dependent Variable } \\
\hline & \multicolumn{4}{|c|}{ Financial Leverage } & \multicolumn{4}{|c|}{ Firm Performance } \\
\hline & \multicolumn{2}{|c|}{ BLEV } & \multicolumn{2}{|c|}{ MLEV } & \multicolumn{2}{|c|}{ TBQ } & \multicolumn{2}{|c|}{ ROA } \\
\hline & Coeff & $P$ value & Coeff & P-Value & Coeff & P-Value & Coeff & P-Value \\
\hline \multicolumn{9}{|c|}{ Corporate Governance } \\
\hline BDS & $\begin{array}{c}- \\
0.149\end{array}$ & $\begin{array}{l}0.001 * * \\
*\end{array}$ & $\begin{array}{c}- \\
0.344\end{array}$ & $\begin{array}{l}0.001 * * \\
*\end{array}$ & - & - & - & - \\
\hline WBD & $\begin{array}{c}- \\
0.168 \\
\end{array}$ & $\begin{array}{l}0.001 * * \\
*\end{array}$ & $\begin{array}{c}- \\
0.045 \\
\end{array}$ & 0.175 & - & - & - & - \\
\hline IBC & 0.245 & $\begin{array}{l}0.001 * * \\
*\end{array}$ & $\begin{array}{c}- \\
0.057\end{array}$ & 0.117 & - & - & - & - \\
\hline ACS & 0.020 & 0.340 & $\begin{array}{c}- \\
0.108 \\
\end{array}$ & $0.012 * *$ & - & - & - & - \\
\hline \multicolumn{9}{|c|}{ Financial Leverage } \\
\hline BLEV & - & - & - & - & 0.324 & $\begin{array}{r}0.001 * * \\
*\end{array}$ & $\begin{array}{r}- \\
0.149\end{array}$ & $\begin{array}{r}0.001 * * \\
*\end{array}$ \\
\hline MLEV & - & - & - & - & $\begin{array}{r}- \\
0.650\end{array}$ & $\begin{array}{r}0.001 * * \\
*\end{array}$ & $\begin{array}{r}- \\
0.557\end{array}$ & $\begin{array}{r}0.001 * * \\
*\end{array}$ \\
\hline
\end{tabular}

Note: ${ }^{* *}$ statistically significant at $5 \% ; * * *$ statistically significant at $1 \%$.

Furthermore, to provide a more complete, clear, and complete illustration of the research model that was built and the results of its analysis, the following Figure 3 is presented.. 


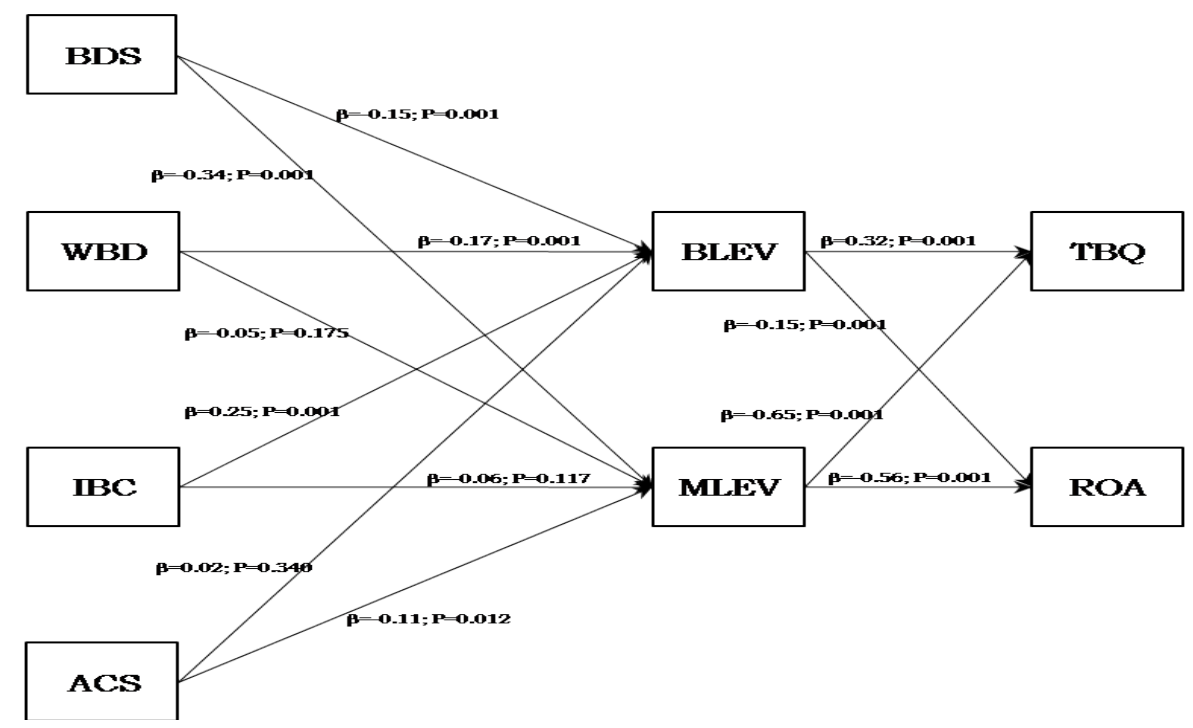

Figure 3. Results in the pictographic model; Source: WarpPLS Output

\section{Discussion of Results}

On the basis of the results of the analysis of the data presented briefly in Table 3 and Figure 1, a more detailed discussion is conducted The discussion is carried out by confirming the results of this study with theories and findings from previous studies.

\section{Effect of Board of Directors Size on Financial Leverage}

The coefficients of the effect of BDS on BLEV and MLEV are $-0.149(\mathrm{P}=0.001)$ and $-0.344(\mathrm{P}=0.001)$, this means a significant negative effect. Thus, Islamic manufacturing companies on the IDX with a larger board of directors size have significantly lower financial leverage, both BLEV and MLEV. This empirical evidence displays that the size of the board of directors of a larger Islamic manufacturing company tends to strongly agree to reduce the financing risk of larger debt. In addition, there is a limit for ISSI category companies to use interest-based debt financing sources, this will encourage the company to meet the additional required funds from internal sources. Therefore, the proportion of debt in the company's capital structure will decrease. Literature on the affiliation among board size and financial leverage in Islamic companies, as far as the authors know, is not yet available, thus, the outcomes of this analysis are confirmed with the results of prior researchs in conventional companies. These results are in line with the Sewpersadh (2019) study on conventional companies, namely companies listed on the Johannesburg Stock Exchange (JSE) which prove that the size of the board of directors has a negative effect on financial leverage. This shows that in principle there is no 
difference in the determinants of capital structure between Islamic and non-Sharia companies, especially for board size.

\section{Influence of Women's Board of Directors on Financial Leverage}

The coefficient of the effect of WBD on BLEV is $-0.168(\mathrm{P}=0.001)$ which means the effect is negative and very significant. The effect of WBD on MLEV is -0.045 $(\mathrm{P}=0.175)$ which means a negative but not significant effect. This empirical evidence shows that Shariah manufacturing companies on the IDX with a larger proportion of female gender on their board of directors have lower debt ratios, especially for BLEV. This is in line with the decisions of their colleagues on the board of directors which also shows a negative influence. Previous studies examining the relationship between women directors and financial leverage in Islamic companies have not been found, thus, the results of this study are confirmed with the findings of studies in conventional companies. This empirical finding is in accordance with the study of Schicks (2014) on conventional companies which states that women are more risk averse than men. The study of Strøm et al. (2014) and Faccio et al. (2016) on conventional companies also prove that entities run by female CEOs have a lower level of leverage than similar entities run by male CEOs. The Adusei \& Obeng study (2019) used a global dataset of 441 conventional microfinance institutions in 69 countries. They prove that women directors have a negative and significant influence on financial leverage. This indicates that the relationship between woman directors and financial leverage in conventional companies can also be proven in Islamic companies.

\section{Pengaruh Independent Board of Commissioners terhadap Financial Leverage}

The results of the analysis showed that the effect of IBC on BLEV was 0.245 $(\mathrm{P}=0.001)$, which means a significant positive effect. The effect of IBC on MLEV is $-0.057(\mathrm{P}=0.117)$, which means that it has no significant negative effect. These results indicate that Shariah manufacturing companies on the IDX that have larger independent members on their board of commissioners are associated with a higher debt ratio (BLEV). This empirical evidence is in line with agency theory (Jensen, 1986), which states that debt can overcome agency problems that occur in companies. The presence of an independent board can guarantee this as indicated by a higher debt ratio. Previous studies examining the relationship between board independent and financial leverage in Islamic companies are 
not yet available, thus, the results of this study are confirmed by the findings of studies in conventional companies. The results of this study are in line with Chow et al. (2018) used a sample of 907 registered conventional non-financial companies from seven Asia Pacific countries during the period 2004-2014. They prove that the independent board has a positive effect on financial leverage. In addition, the results of this study are in accordance with the study of Zaid et al. (2020) using data obtained from the annual reports of conventional companies listed on the Palestine Stock Exchange (PEX) for a six-year period (2013-2018). They found a positive relationship between the number of independent boards and financial leverage. Jiraporn et al. (2012) revealed that an independent board will have knowledge and information that allows the company to use higher leverage. This evidence shows that the relationship between independent boards and financial leverage in conventional companies is also found in Islamic companies.

\section{Effect of Audit Committee Size on} Financial Leverage

The coefficient of the effect of ACS on BLEV is $0.020(\mathrm{P}=0.340)$ which means that the effect is positive but not significant. The effect of ACS on MLEV is $-0.108(\mathrm{P}=0.012)$ which means that it has a negative and significant effect at the 5\% level of neglect. These results state that Islamic manufacturing companies on the IDX with larger audit committee sizes have smaller market leverage (MLEV). The MLEV calculation includes the market value of the company's assets, namely the current value of assets in place and the asset value of the company's opportunity to grow in the future (Yildirim et al., 2018). Previous studies that examined the relationship between audit committee size and financial leverage in Islamic companies have not been found, thus, the results of this study are confirmed by the findings of studies in conventional companies. The results of this study are in accordance with the study of Chen et al. (2016) on conventional non-financial companies using data obtained from the compustat global database for the period 1992 to 2009. They conclude that better audited financial statements will provide creditors with important additional information about the company's credit risk. That information can lead to stringent credit approvals, thereby affecting a company's likelihood of obtaining a loan. In addition, the negative influence of ACS on MLEV is also in line with the decision of the board of directors. 
Effect of Financial Leverage on Firm Performance

The coefficient of effect of BLEV on TBQ is $0.324(\mathrm{P}=0.001)$, this indicates that Islamic manufacturing companies on the IDX with larger BLEVs have higher market performance (TBQ). Agency theory explains that debt can reduce agency costs between managers and shareholders, because debt can prevent managers from financing projects with a negative NPV (Jensen, 1986). This evidence is consistent with the trade-off theory which explains that more profitable companies will bear lower costs of financial distress, which results in cheaper debt financing (Myers \& Majluf, 1984). Debt financing will encourage managers to work more productively, efficiently and profitably, and therefore the market responds with a higher value. Previous studies that tested the relationship between BLEV and market performance (TBQ) in Islamic companies have not been found, so the results of this study are confirmed with the results of studies in conventional companies. Therefore, the results of this study are in line with the study of Detthamrong et al. (2017), and Ramli et al., (2019) who found a positive relationship between BLEV and firm's market performance.

The coefficient of the effect of MLEV on TBQ is $-0.650(\mathrm{P}=0.001)$, which is a very significant negative effect. This indicates that Shariah manufacturing companies on the IDX with larger MLEVs have lower market performance (TBQ). A large MLEV value indicates the low market value of the company's equity, so the negative effect of MLEV on TBQ is logical. Previous studies examining the relationship between MLEV and TBQ in Islamic companies have not been found, so the results of this study are confirmed with the findings of studies in conventional companies. The results of this study are in accordance with Le \& Phan (2017) who use conventional non-financial companies listed on the Vietnam stock market for the period 2007-2012. They proved MLEV was negatively and significantly related to Tobin's Q.

The coefficient of the effect of BLEV on ROA is $-0.149(\mathrm{P}=0.001)$, this indicates that Islamic manufacturing companies on the IDX with higher BLEV are associated with lower book performance (ROA). This evidence is in accordance with the peckingorder theory which explains that there is asymmetric information between managers and investors, causing company managers to prefer funding from sources with the lowest risk order (Chakraborty, 2010). The pecking-order theory shows that leverage has a negative effect on profitability (Çekrezi, 2013). The relationship between financial leverage (BLEV) and firm 
performance (ROA) in ISSI (Sharia) category manufacturing companies on the IDX does not show specific differences with conventional companies. This is also proven by Yildirim et al. (2018) which compares the determinants of capital structure between Shari'ah Compliant firms (SC) and Shari'ah Non-Compliant (SNC) in seven countries and seven industries. They prove that Profitability (ROA) is negatively related to BLEV and MLEV, both for SC and SNC. Furthermore, this finding is in line with Le \& Phan (2017) using conventional nonfinancial companies listed on the Vietnamese stock market for the period 2007-2012. They prove that the debt ratio (BLEV) negatively affects the company's book performance (ROA). In addition, the results of this study are in line with the Dawar study (2014) which used a sample of 78 companies listed in the Center for Monitoring Indian Economy (CMIE) for the period 2003 to 2012 which represented almost all major sectors of the Indian economy. except for the banking and financial sectors. Dawar's study (2014) reports that there is a negative relationship between debt ratio (BLEV) and ROA.

The coefficient of the effect of MLEV on ROA is $-0.557(\mathrm{P}=0.001)$, this means that companies with larger MLEVs have lower book performance (ROA). The large MLEV value is due to the low market value of the company's equity. The low market value of equity, of course, is more due to the low performance of the company as a whole, so the negative effect of MLEV on ROA is logical. Previous studies that tested the relationship between MLEV and ROA in Islamic companies have not been found, so the results of this study are confirmed with the findings of studies in conventional companies. The results of this study are in line with the study of Le \& Phan (2017) which proves that Market Leverage (MLEV) negatively affects Return on Assets (ROA).

\section{Conclusion}

Based on the results of this study, it can be concluded that: Board of directors size of Islamic manufacturing companies has a negative effect on book leverage and market leverage; Woman's board of directors Islamic manufacturing companies have a negative effect on book leverage, but no significant effect on market leverage; Independent board of commissioners of Islamic manufacturing companies has a positive effect on book leverage, but it has no significant effect on market leverage; The audit committee size of Islamic manufacturing companies has a negative effect on market leverage, but it has no significant effect on book leverage. Furthermore, Book leverage (BLEV) of Islamic manufacturing companies shows a 
positive effect on market performance (TBQ) and negative on book performance (ROA). Market leverage (MLEV) of Islamic manufacturing companies shows a positive effect, both on market performance (TBQ) and on book performance (ROA).

This paper contributes to the financial literature of Islamic companies, especially for manufacturing companies, in identifying corporate governance as a determinant of financial leverage, and the effect of financial leverage on firm performance. In principle, the effect of corporate governance on financial leverage and the effect of financial leverage on firm performance, there is no difference between Islamic and non-Sharia companies. This paper provides additional insight for investors on the Indonesia Stock Exchange, regarding the relationship between corporate governance, financial leverage, and firm performance of Islamic manufacturing, which can be used as material for consideration in making investments.

This paper has several limitations, therefore the agenda for further studies is suggested to consider the ownership structure and characteristics of the CEO as a proxy for corporate governance variables. In addition, company-specific factors and macroeconomic conditions also need to be considered as determinants of the capital structure. Finally, it is advisable to consider doing research on other groups of companies.

\section{Bibliography}

Adusei, M., \& Obeng, E. Y. T. (2019). Board gender diversity and the capital structure of microfinance institutions: A global analysis. Quarterly Review of Economics and Finance, 71, 258-269. https://doi.org/10.1016/j.qref.2018.09. 006

Al-ahdal, W. M., Alsamhi, M. H., Tabash, M. I., \& Farhan, N. H. S. (2020). The impact of corporate governance on financial performance of Indian and GCC listed firms: An empirical investigation. Research in International Business and Finance, 51(August 2019). https://doi.org/10.1016/j.ribaf.2019.10 1083

Anderson, R. C., Mansi, S. A., \& Reeb, D. M. (2004). Board characteristics, accounting report integrity, and the cost of debt. Journal of Accounting and Economics, 37(3), 315-342. https://doi.org/10.1016/j.jacceco.2004. 01.004

Chakrabarti, A., \& Chakrabarti, A. (2019). The capital structure puzzle - evidence from Indian energy sector. International Journal of Energy Sector Management, $\quad$ 13(1), 2-23. 
https://doi.org/10.1108/IJESM-032018-0001

Chakraborty, I. (2010). Capital structure in an emerging stock market: The case of India. Research in International Business and Finance, 24(3), 295-314. https://doi.org/10.1016/j.ribaf.2010.02. 001

Chancharat, N., Krishnamurti, C., \& Tian, G. (2012). Board structure and survival of new economy IPO firms. Corporate Governance: An International Review, 20(2). https://doi.org/10.1111/j.14678683.2011.00906.x

Chang, Y. K., Chou, R. K., \& Huang, T. H. (2014). Corporate governance and the dynamics of capital structure: New evidence. Journal of Banking and Finance, $\quad 48, \quad 374-385$. https://doi.org/10.1016/j.jbankfin.2014 .04 .026

Chen, P. F., He, S., Ma, Z., \& Stice, D. (2016). The information role of audit opinions in debt contracting. Journal of Accounting and Economics, 61(1), 121-144.

https://doi.org/10.1016/j.jacceco.2015. 04.002

Chow, Y. P., Muhammad, J., Bany-Ariffin, A. N., \& Cheng, F. F. (2018). Macroeconomic uncertainty, corporate governance and corporate capital structure. International Journal of
Managerial Finance, 14(3), 301-321. https://doi.org/10.1108/IJMF-08-20170156

Connelly, J. T., Limpaphayom, P., \& Nagarajan, N. J. (2012). Form versus substance: The effect of ownership structure and corporate governance on firm value in Thailand. Journal of Banking and Finance, 36(6), 17221743.

https://doi.org/10.1016/j.jbankfin.2012 .01 .017

Danso, A., Lartey, T. A., Gyimah, D., \& Adu-Ameyaw, E. (2020). Leverage and performance: do size and crisis matter? Managerial Finance. https://doi.org/10.1108/MF-10-20190522

Dawar, V. (2014). Agency theory, capital structure and firm performance: some Indian evidence. Managerial Finance, $40(12)$, 1190-1206. https://doi.org/10.1108/MF-10-20130275

Degryse, H., de Goeij, P., \& Kappert, P. (2012). The impact of firm and industry characteristics on small firms' capital structure. Small Business Economics, $38(4)$, 431-447. https://doi.org/10.1007/s11187-0109281-8

Detthamrong, U., Chancharat, N., \& Vithessonthi, C. (2017). Corporate 
governance, capital structure and firm performance: Evidence from Thailand. Research in International Business and Finance, 42(July), 689-709. https://doi.org/10.1016/j.ribaf.2017.07. 011

Dimitropoulos, P. (2014). Capital structure and corporate governance of soccer clubs: European evidence. Management Research Review, 37(7), 658-678. https://doi.org/10.1108/MRR-092012-0207

Elmagrhi, M. H., Ntim, C. G., Malagila, J., Fosu, S., \& Tunyi, A. A. (2018). Trustee board diversity, governance mechanisms, capital structure and performance in UK charities. Corporate Governance (Bingley), 18(3), 478-508. https://doi.org/10.1108/CG-08-20170185

Faccio, M., Marchica, M. T., \& Mura, R. (2016). CEO gender, corporate risktaking, and the efficiency of capital allocation. Journal of Corporate Finance, 39, 193-209. https://doi.org/10.1016/j.jcorpfin.2016 .02 .008

Feng, Y., Hassan, A., \& Elamer, A. A. (2020). Corporate governance, ownership structure and capital structure: evidence from Chinese real estate listed companies. International Journal of Accounting \& Information Management, ahead-of-p(ahead-ofprint). https://doi.org/10.1108/IJAIM04-2020-0042

Hussainey, K., \& Aljifri, K. (2012). Corporate governance mechanisms and capital structure in UAE. Journal of Applied Accounting Research, 13(2), 145-160.

https://doi.org/10.1108/096754212112 54849

Imamah, N., Lin, T. J., Suhadak, Handayani, S. R., \& Hung, J. H. (2019). Islamic law, corporate governance, growth opportunities and dividend policy in Indonesia stock market. Pacific Basin Finance Journal, 55(December 2017), 110-126. https://doi.org/10.1016/j.pacfin.2019.0 3.008

Jensen, M. C. (1986). Agency costs of free cash flow, corporate finance, and takeovers. American Economic Association, $\quad 76(2), \quad$ 323-329. https://doi.org/10.1017/cbo978051160 9435.005

Jiraporn, P., Kim, J. C., Kim, Y. S., \& Kitsabunnarat, P. (2012). Capital structure and corporate governance quality: Evidence from the Institutional Shareholder Services (ISS). International Review of Economics and 
Finance, 22(1), 208-221. https://doi.org/10.1016/j.iref.2011.10.0 14

Le, T. P. V., \& Phan, T. B. N. (2017). Capital structure and firm performance: Empirical evidence from a small transition country. Research in International Business and Finance, 42(July), 710-726. https://doi.org/10.1016/j.ribaf.2017.07. 012

Li, K., Niskanen, J., \& Niskanen, M. (2019). Capital structure and firm performance in European SMEs: Does credit risk make a difference? Managerial Finance, 45(5), 582-601. https://doi.org/10.1108/MF-01-20170018

Martín, S. P., \& Saona, P. (2017). Capital structure in the Chilean corporate sector: Revisiting the stylized facts. Research in International Business and Finance, 40, 163-174. https://doi.org/10.1016/j.ribaf.2017.01. 004

Modigliani, F., \& Miller, M. H. (1958). The Cost of Capital, Corporation Finance and the Theory of Investment. The American Economic Review, 48(3), 261-297.

https://doi.org/10.2307/1286430

Myers, S. C., \& Majluf, N. S. (1984). Corporate financing and investment decisions when firms have information that investors do not have. Journal of Financial Economics, 13(2), 187-221. https://doi.org/10.1016/0304405X(84)90023-0

Panda, B., \& Leepsa, N. M. (2017). Agency theory: Review of theory and evidence on problems and perspectives. Indian Journal of Corporate Governance, 10(1), 74-95. https://doi.org/10.1177/097468621770 1467

Piaw, L. L. T., \& Jais, M. (2014). The Capital Structure of Malaysian Firms in the Aftermath of Asian Financial Crisis 1997. Journal of Global Business and Economics, 8(1), 24-41.

Ramli, N. A., Latan, H., \& Solovida, G. T. (2019). Determinants of capital structure and firm financial performance-A PLS-SEM approach: Evidence from Malaysia and Indonesia. Quarterly Review of Economics and Finance, 71, 148-160. https://doi.org/10.1016/j.qref.2018.07. 001

Schicks, J. (2014). Over-indebtedness in microfinance - An empirical analysis of related factors on the borrower level. World Development, 54, 301-324. https://doi.org/10.1016/j.worlddev.201 3.08 .009

Sewpersadh, N. S. (2019). A theoretical and 
Mai, Muhamad Umar et al., Corporate Governance, Financial Leverage and Performance.....

econometric evaluation of corporate governance and capital structure in JSE-listed companies. Corporate Governance (Bingley), 19(5), 10631081. https://doi.org/10.1108/CG-082018-0272

Strøm, R. Ø., D’Espallier, B., \& Mersland, R. (2014). Female leadership, performance, and governance in microfinance institutions. Journal of Banking and Finance, 42(1), 60-75. https://doi.org/10.1016/j.jbankfin.2014 .01 .014

Usman, M., Farooq, M. U., Zhang, J., Makki, M. A. M., \& Khan, M. K. (2019). Female directors and the cost of debt: does gender diversity in the boardroom matter to lenders? Managerial Auditing Journal, 34(4), 374-392.

https://doi.org/10.1108/MAJ-04-20181863

Vo, X. V., \& Ellis, C. (2017). An empirical investigation of capital structure and firm value in Vietnam. Finance Research Letters, 22, 90-94. https://doi.org/10.1016/j.frl.2016.10.0 14

Yildirim, R., Masih, M., \& Bacha, O. I. (2018). Determinants of capital structure: evidence from Shari'ah compliant and non-compliant firms. Pacific Basin Finance Journal, 51,
198-219.

https://doi.org/10.1016/j.pacfin.2018.0

6.008

Zaid, M. A. ., Wang, M., T.F. Abuhijleh, S., Issa, A., W.A. Saleh, M., \& Ali, F. (2020). Corporate governance practices and capital structure decisions: the moderating effect of gender diversity. Corporate Governance (Bingley), 20(5), 939-964. https://doi.org/10.1108/CG-11-20190343

Zelechowski, D. D., \& Bilimoria, D. (2004). Characteristics of Women and Men Corporate Inside Directors in the US. Corporate Governance, 12(3), 337-342. https://doi.org/10.1111/j.14678683.2004.00374.x 